\title{
A model to search for birth probabilities of mammal populations using fertility data
}

\author{
Moreira, JR. ${ }^{\mathrm{a} *}$, Eagle, M. ${ }^{\mathrm{b}}$, Gillespie, OJ. ${ }^{\mathrm{b}}$, Davidson, $\mathrm{.}^{\mathrm{b}}$, \\ Marriott, FHC. ${ }^{\mathrm{b}}$ and Macdonald, DW. ${ }^{\mathrm{c}}$ \\ ${ }^{a}$ Embrapa Recursos Genéticos e Biotecnologia, \\ PqEB, Final W5, Norte, CEP 70770-900, Brasília, DF, Brazil \\ bDepartment of Statistics, University of Oxford, \\ 1 South Parks Road, Oxford, OX1 3TG, UK \\ ${ }^{c}$ Wildlife Conservation Research Unit, \\ Department of Zoology, University of Oxford, South Parks Road, Oxford OX1 3PS, UK \\ *e-mail: jmoreira@ cenargen.embrapa.br \\ Received February 13, 2008 - Accepted May 20, 2009 - Distributed November 30, 2009
}

(With 3 figures)

\begin{abstract}
A model was constructed to predict monthly birth probabilities using mammalian fertility data. We used a sample of 147 female capybaras (Hydrochoerus hydrochaeris) hunted on a farm on Marajó Island, Brazil. In the model each month was treated as a multinomial with six cells representing the six possible reproductive states (five months gestation). A hypothesis test was carried out to see whether a cosine curve would fit the birth probabilities. The results offer no support for a seasonal component $\left(\mathrm{F}_{2.9}=1.84, \mathrm{P}=0.21\right)$, whereas results from a direct census do $\left(\mathrm{F}_{3.23}=87.29\right.$, $\mathrm{P}<0.01)$. Some hunting techniques were biased towards killing pregnant females $\left(\chi_{1}^{2}=7.2, \mathrm{P}<0.01\right)$, thereby spreading reproduction throughout the year $\left(\mathrm{F}_{2,9}=1.84, \mathrm{P}=0.21\right)$. The model remained a powerful predictive tool to be used with mammalian fertility data as long as the data are not biased towards pregnant females.
\end{abstract}

Keywords: capybara, Hydrochoerus hydrochaeris, model, breeding season, fertility.

\section{Um modelo para busca por probabilidades de nascimentos de populações de mamíferos utilizando dados de fertilidade}

\section{Resumo}

Um modelo foi desenvolvido para predizer as probabilidades de nascimentos mensais utilizando dados de fertilidade de mamíferos. Utilizamos uma amostra de 147 fêmeas de capivaras (Hydrochoerus hydrochaeris) caçadas em fazenda da Ilha de Marajó, Brasil. Cada mês foi tratado no modelo como um multinômio com seis células representando os seis possíveis estados reprodutivos (cinco meses de gestação). Um teste de hipótese foi realizado para avaliar se uma curva cossena se ajustava às probabilidades de nascimentos. Os resultados não apoiaram um componente sazonal $\left(F_{2,9}=1,84, P=0,21\right)$, enquanto houve apoio por parte dos resultados de censo direto $\left(F_{3,23}=87,29, P<0,01\right)$. Algumas técnicas de abate eram tendenciosas ao abate de fêmeas prenhas $\left(\chi_{1}^{2}=7,2, \mathrm{P}<0,01\right)$, consequentemente dispersando a reprodução por todo o ano $\left(\mathrm{F}_{2.9}=1,84, \mathrm{P}=0,21\right)$. O modelo continuou como uma poderosa ferramenta de previsão para uso com dados de fertilidade de mamíferos, desde que os dados não se encontrem tendenciosos para fêmeas prenhas.

Palavras-chave: capivara, Hydrochoerus hydrochaeris.

\section{Introduction}

Birth season information is a fundamental tool for the development of fecundity tables, life tables and for modeling the harvest of mammalian populations (Caughley, 1977). In most models of population dynamics, increases in population due to birth are differently adjusted if the species has a birth-pulse or a birth-flow reproduction (Tang and Chen, 2002). Birth season can also provide important information for the understanding of a species' population ecology, for wildlife control and for conservation issues (Caswell, 1989).

The capybara (Hydrochoerus hydrochaeris Linnaeus, 1766) is a large semi-aquatic polygynous New World hystricomorph rodent (Macdonald, 2006; Oliveira and Bonvicino, 2006). It is of considerable interest to conservation biologists not only because it is harvested in diverse ways - from subsistence hunting to organised 
culls - and lives in habitats increasingly used for intensive cattle production, but also because it is a candidate for domestication.

Both in the context of evaluating the sustainability of bush meat harvests, and the context of calculating sustainable yields, the reproductive parameters of populations are crucial. Cropping regimes of highly productive species usually need to be unbiased in relation to sex to avoid a reduction in fertility due to a reduced number of males (Ginsberg and Milner-Gulland, 1994; Moreira and Macdonald, 1995; Milner et al., 2007). Sex-biased hunting can lead to unexpected and often undesirable consequences (Keyser et al., 2006). It is also difficult to determine sex prior to slaughter in some species and when certain hunting techniques are used (Moreira and Macdonald, 1997; Gordon et al., 2004). The result is that there is usually a large amount of information available about female fertility after a large cull. Furthermore, ultrasonography and hormonal levels have been used as non-invasive reproductive assessment techniques for pregnancy diagnosis and accurate prediction of conception date (Gonzalez et al., 2004; Karen et al., 2006). Therefore, in this paper we seek to develop a general method that can be used simply to predict birth probabilities from mammalian fertility data.

\section{Material and Methods}

The data were collected at Fazenda Eco-búfalos $\left(0^{\circ} 15^{\prime} \mathrm{S}\right.$ and $\left.48^{\circ} 50^{\prime} \mathrm{W}\right)$, a ranch located on the seasonally flooded savannahs of Marajó Island in the mouth of the Amazon, State of Pará, Brazil. For the development of the model, a sample of 147 female capybara from those hunted in 1991-1992 by the ranchers on this farm was examined.

The model to search for birth probabilities Standard regression techniques were applied to capybara conceptus $(0,30$ and 60 days $)$ or foetal weight (60, 90, 100, 120 and 140 days) (López-Barbella, 1987) and birth weight (Ojasti, 1973) to produce two equations to estimate time of gestation. The $35^{\text {th }}$ day of pregnancy $(23 \%)$ was chosen as the $t_{0}$, after which the cubic growth function was applied to foetal weight, according to Huggett and Widdas (1951). For the periods before $t_{0}$ (Equation 1: $r^{2}=0.99$ ) and after $\mathrm{t}_{0}$ (Equation 2: $\mathrm{r}^{2}=0.99$ ), the following models were found:

$\mathrm{W}_{\mathrm{c}}=\left(0.291778+5.45326 \times 10^{-5} \mathrm{t}^{3}\right)^{2}$

$\mathrm{W}_{\mathrm{f}}=-43.2513+4.41423 \times 10^{-4} \mathrm{t}^{3}$

where $\mathrm{W}_{\mathrm{c}}$ is conceptus weight in grams, $\mathrm{W}_{\mathrm{f}}$ is foetal weight in grams and $t$ is time of gestation in days. These equations were used to estimate birth date or stage of gestation.

For the selection of the model, pregnancy time (that is, the age in months of the embryo) was classified as a discrete variable. Time was divided up into months so that at the beginning of each month a given female from the hunting dataset was allocated to one of six states. These were labeled: 1) not-pregnant; 2) 0-1 months pregnant; 3) 1-2 months pregnant; 4) 2-3 months pregnant; 5) 3-4 months pregnant; 6) 4-5 months pregnant, since a capybara gestation is five months long (López-Barbella, 1987).

Thus, each month was taken as having a multinomial distribution with six cells. The hunting data were hence condensed into a matrix ("y" matrix) where the $(i, j)$ element is the number of female capybara in state $\mathrm{j}$ at the beginning of month i. Letting $g$ and $\mathrm{g}^{\mathrm{v}}$ be the states of pregnant and not-pregnant, the parameterization decided upon was:

$\pi_{i}=$ proportion not pregnant at start of month $i$;

$\lambda_{i}=\operatorname{Pr}($ a female is $g$ at the start of month $i+1 \mid$ the female is $\breve{g}$ at the start of month i).

Therefore, $\lambda_{i}$ is the conditional probability of becoming pregnant in month $\mathrm{i}$ (a female conceives only if it is not already pregnant). The probabilities of the various states for the month's multinomials were worked out in the following way:

$\operatorname{Pr}($ state 1 at start of month $\mathrm{i})=\pi_{\mathrm{i}}$;

$\operatorname{Pr}($ state $\mathrm{j}$ at start of month $\mathrm{i})=\operatorname{Pr}($ between $\mathrm{j}-2$ and j-1 months pregnant at month $\mathrm{i}$ );

$=\operatorname{Pr}($ became pregnant in month $\mathrm{i}-\mathrm{j}+1)$;

$=\pi_{i-j+1} \lambda_{i-j+1}$ for $\mathrm{j} \geq 2$.

The log-likelihood equation (Equation 3) for all months was therefore:

$\mathrm{L}(\lambda, \pi)=\sum_{\mathrm{i}=1}^{12}\left\{\mathrm{y}_{\mathrm{i} 1} \log \pi_{\mathrm{i}}+\sum_{\mathrm{j}=2}^{6} \mathrm{y}_{\mathrm{ij}} \log \lambda_{\mathrm{i}-\mathrm{j}+1} \pi_{\mathrm{i}-\mathrm{j}+1}\right\}$

The parameterization previously described leads to the following relationship between the $\lambda$ 's and the $\pi$ 's:

$\operatorname{Pr}\left(\right.$ a female is $g^{v}$ at month $\left.\mathrm{i}+1\right)=\operatorname{Pr}\left(g^{v}\right.$ at month $\mathrm{i}+1 \mid \breve{g}$ at month i)Pr ( $\breve{g}$ at month i) + Pr ( $\breve{g}$ at month i + 1 and $g$ at the start of month i);

This is the probability of becoming not pregnant in month $i+1$. The second term is the unconditional probability of giving birth in month $i$ (which is equivalent to the unconditional probability of conceiving five months before). Using this parameter the following identity could also be established:

$\pi_{\mathrm{i}+1}=\left(1-\lambda_{\mathrm{i}}\right) \pi_{\mathrm{i}}+\lambda_{\mathrm{i}-5} \pi_{\mathrm{i}-5}$

Therefore, in order to obtain the $\pi$ vector from the $\lambda$ 's, the likelihood equation (Equation 3) was reduced to a function only of $\lambda$ (Figure 1). The function chosen to maximise the log-likelihood was the S-Plus function "nlmin" (Press et al., 1993).

The "y" matrix was turned into a matrix of proportions where each element was replaced by the quotient of itself and its row total, so that the $(i, j)$ element represented the proportion of female capybara in state $j$ at the beginning of month $\mathrm{i}$.

A hypothesis test was carried out to evaluate whether a cosine curve would fit the months' birth probabilities. 


$$
\left(\begin{array}{rrrrrrrrrrrr}
0 & 0 & 0 & 0 & 0 & 0 & \lambda_{7} & 0 & 0 & 0 & 0 & 1-\lambda_{12} \\
1-\lambda_{1} & 0 & 0 & 0 & 0 & 0 & 0 & \lambda_{8} & 0 & 0 & 0 & 0 \\
0 & 1-\lambda_{2} & 0 & 0 & 0 & 0 & 0 & 0 & \lambda_{9} & 0 & 0 & 0 \\
0 & 0 & 1-\lambda_{3} & 0 & 0 & 0 & 0 & 0 & 0 & \lambda_{10} & 0 & 0 \\
0 & 0 & 0 & 1-\lambda_{4} & 0 & 0 & 0 & 0 & 0 & 0 & \lambda_{11} & 0 \\
0 & 0 & 0 & 0 & 1-\lambda_{5} & 0 & 0 & 0 & 0 & 0 & 0 & \lambda_{12} \\
\lambda_{1} & 0 & 0 & 0 & 0 & 1-\lambda_{6} & 0 & 0 & 0 & 0 & 0 & 0 \\
0 & \lambda_{2} & 0 & 0 & 0 & 0 & 1-\lambda_{7} & 0 & 0 & 0 & 0 & 0 \\
0 & 0 & \lambda_{3} & 0 & 0 & 0 & 0 & 1-\lambda_{8} & 0 & 0 & 0 & 0 \\
0 & 0 & 0 & \lambda_{4} & 0 & 0 & 0 & 0 & 1-\lambda_{9} & 0 & 0 & 0 \\
0 & 0 & 0 & 0 & \lambda_{5} & 0 & 0 & 0 & 0 & 1-\lambda_{10} & 0 & 0 \\
0 & 0 & 0 & 0 & 0 & \lambda_{6} & 0 & 0 & 0 & 0 & 1-\lambda_{11} & 0
\end{array}\right)
$$

Figure 1. The A matrix, where the likelihood Equation 3 was reduced to a function only of $\lambda$, which is of dimension twelve.

probability $=\beta_{1} \cos (2 \pi \mathrm{t} / 12)+\beta_{2} \sin (2 \pi \mathrm{t} / 12)$

An analysis of variance of this fitted model would show whether a seasonal effect is likely to be present in the capybara breeding pattern.

Checking the results - The resulting birth probabilities of the model were compared with those from census counts. An area spared from hunting for over 15 years was chosen on this same farm for the census counts. The animals were counted using a direct census, at threemonthly intervals (trimesters), along three transects with two replicates. Two main classes, young and adults, were used to classify the animals. Two of the transects were counted in opposite directions to check the accuracy of the census method in relation to the position of the censor.

An analysis of variance, with the response variable as the proportion of young, was used to evaluate variation throughout the year. A Tukey Test was used to detect differences in the proportion of young along the year.

\section{Results}

The probability of giving birth for each month was calculated and is shown in Figure 2. There is clear evidence that capybara on Marajó Island breed throughout the year. The monthly pattern was irregular, with apparent peaks in the number of births in February, September, and November and contrasting low probabilities of birth in the intervening months. The analysis of variance results offer no support for the hypothesis that capybara birth has a seasonal component on Marajó Island (Table 1).

The comparison with the census data - The census data revealed obvious seasonality in the births of capybaras on Marajó Island (Figure 3). Analysis of variance revealed that the only factor that had a statistically sig-

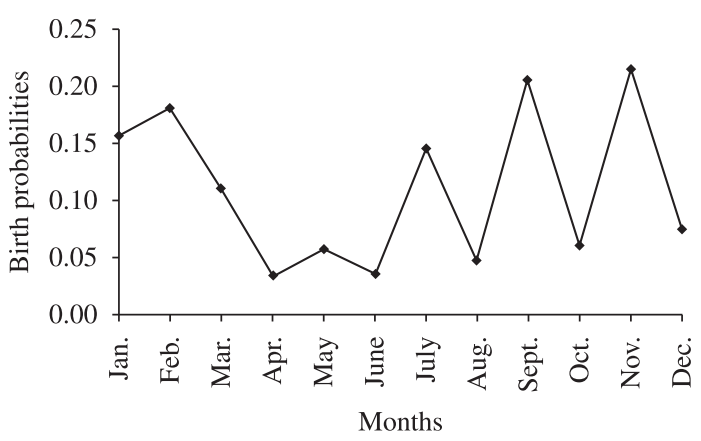

Figure 2. Probability of giving birth calculated for each month using the log-likelihood function on the capybara hunting data.

Table 1. Analysis of variance table from the cosine curve model for birth probabilities from the capybara hunting data.

\begin{tabular}{lccc}
\hline $\begin{array}{c}\text { Main } \\
\text { effects }\end{array}$ & $\begin{array}{c}\text { Degrees of } \\
\text { Freedom }\end{array}$ & F-ratio & $\begin{array}{c}\text { Significant } \\
\text { Level }\end{array}$ \\
\hline $\cos (2 \pi \mathrm{t} / 12)$ & 1 & 3.69 & 0.08 \\
$\sin (2 \pi \mathrm{t} / 12)$ & 1 & 0.26 & 0.62 \\
Total & 2 & 1.84 & 0.21 \\
Residual & 9 & - & - \\
Total & 11 & - & - \\
\hline
\end{tabular}

nificant effect on the proportion of young observed in the censused population was trimester $\left(\mathrm{F}_{3,23}=87.29\right.$, $\mathrm{P}<0.01)$. There were no significant interactions between explanatory variables. Replicate had little effect on the proportion of young $\left(\mathrm{F}_{1,23}=0.13, \mathrm{P}=0.74\right)$ and neither did the direction of viewing $\left(\mathrm{F}_{1,13}=0.17, \mathrm{P}=0.71\right)$. 


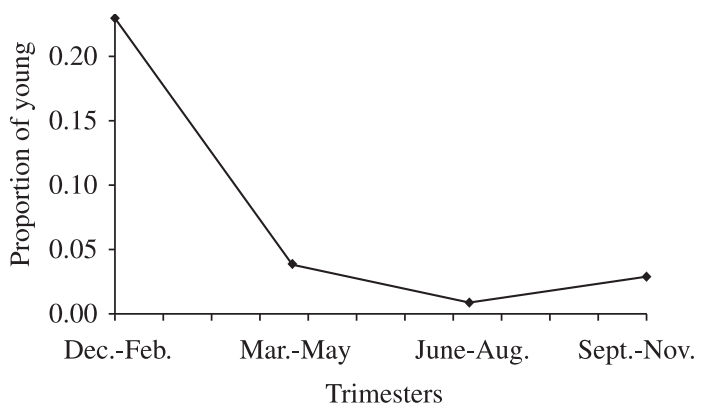

Figure 3. Proportion of young in the population calculated for each trimester using the capybara census data.

The mean values calculated by the Tukey Test for the four trimesters have shown that the proportion of young capybaras during the December-February trimester (which is the early rainy season) was higher $(\mathrm{P}<0.05)$ than during the other three.

The effect of hunting technique - These results for birth seasons of capybara suggest that the hunting data might have been biased by differences in their collection. We found that the hunters at Fazenda Eco-búfalos used two families of techniques. In one case the capybaras were stalked at night (generally by boat), dazzled with a spotlight; in the other they were chased (by boat or on foot) until exhaustion.

We deduced that an important difference between these was that exhaustion played a role in the sample of animals killed by the latter method. In particular, female capybara can put on approximately $15 \%$ of their body weight during late pregnancy (Moreira and Macdonald, 1996), and therefore are expected to tire more easily and to be less athletic.

The hunters tended to use one technique predominantly in some months, and the other technique in other months, thereby confounding comparisons between them. However, in two months the hunters used both of the two hunting techniques in approximately equal measure, allowing a comparison between their selectivity. This revealed that a significantly higher proportion of pregnant females was represented in the chased rather than stalked sample $\left(\chi_{1}^{2}=7.2, \mathrm{P}<0.01\right)$.

\section{Discussion}

The seasonal component in capybara birth that was clear in the census data was at odds with the results from the hunting data. The census technique used can be exposed to some bias since the age classification is subjective. On the other hand, however, confidence in the census data is supported by the fact that replicate and the direction of viewing had little effect on the proportion of young. Therefore, we feel justified in trusting the census data result.
Our analyses reveal clear statistical evidence of a bias in hunting methods, which is readily interpreted as arising from pregnant females being prone to exhaustion when chased. It seems that the biased effect of some of the hunting techniques used, towards pregnant females, exaggerated the spread of reproductive effort of capybaras throughout the year and diluted the seasonality of breeding.

When using his hunting data Ojasti (1973) found capybara reproduction in Venezuela to be spread throughout the year ( $80 \%$ pregnant females found from April to November). Nevertheless, when using his census data he found $79 \%$ of the births occurring between September and December. In Venezuela, the most common hunting technique for capybara involves chasing the animals on horseback (Macdonald, 2006). This is also a technique that can involve exhausting the animals. Therefore, it is obvious that exhaustion biased Ojasti's (1973) hunting data result as it did ours.

Exposing biases in the hunted sample is not a reason to abandon the discrete time model, but on the contrary, it provides an opportunity to refine its use, especially with the use of non-invasive reproductive assessment techniques (Karen et al., 2006). The model can only be used safely when such biases have been weeded out, or at least their impact measured.

The irregular monthly pattern of the hunting model raises the possibility that there were high correlations between parameters used (states and months). This seems unlikely, however, because each birth probability was calculated from different cells in the "y" matrix, which are assumed to be independent. Therefore, the reliability of the model to predict birth probabilities from fertility data should be trusted, as long as there is no bias in the data collection. The only flaw in the model is the fact that it needs data to be collected in several different months of the year, which might be a difficult task for organised culls and for endangered species. The time gap between data collections (and therefore their frequency) depends on the length of the species' gestation period. Nevertheless, this problem concerns the variable studied (fertility), and any other technique used for the study of birth probabilities will also need data collected throughout the year. The resulting information might be useful for simulations of mammalian single-species population dynamics (Gao and Chen, 2005).

Proof that methods involving chasing selection for pregnant females is itself relevant to planning the conservation and management of capybaras. A disproportionate cull of pregnant females is exactly the opposite outcome to that required by any system of sustainable use (Gordon et al., 2004). This, together with welfare considerations, leads us to suggest that guidelines or regulations regarding capybara harvests should veto or severely restrict the use of methods involving chasing during the peak breeding season. The non-random impacts of different hunting methods should be taken into 
account in considering management plans for this emblematic Neotropical species.

Acknowledgements - This work was supported by a grant to J.R.M. from the Conselho Nacional de Desenvolvimento Científico e Tecnológico (Brazil) and partially funded by the International Foundation for Science (Sweden), Wildlife Conservation International (USA) and Fundação de Apoio à Pesquisa Família Alencar (Brazil). The authors wish to thank S. Casement and J. Colbourne for editorial suggestions. We are grateful for the assistance and hospitality of the Lobato family and especially the help of their staff at Fazenda Eco-búfalos.

\section{References}

CASWELL, H., 1989. Matrix Population Models: construction, analysis, and interpretation. Sunderland: Sinauer Associates Inc. 328 p.

CAUGHLEY, G., 1977. Analysis of Vertebrate Populations. Chichester: John Wiley \& Sons. 234 p

GAO, S. and CHEN, L., 2005. Dynamic complexities in a single-species discrete population model with stage structure and birth pulses. Chaos, Solitons and Fractals, vol. 23, no. 2, p. $519-527$.

GINSBERG, JR. and MILNER-GULLAND, EJ., 1994. Sexbiased harvesting and population dynamics in ungulates: implications for conservation and sustainable use. Conservation Biology, vol. 8, no. 1, p. 157-166.

GONZÁLEZ, F., CABRERA, F., BATISTA, M., RODRÍGUEZ, N., ÁLAMO, D., SULON, J., BECKERS, JF. and GRACIA, A., 2004. A comparison of diagnosis of pregnancy in the goat via transrectal ultrasound scanning, progesterone, and pregnancyassociated glycoprotein assays. Theriogenology, vol. 62, no. 6 , p. $1108-1115$.

GORDON, IJ., HESTER, AJ. and FESTA-BIANCHET, M., 2004. The management of wild large herbivores to meet economic, conservation and environmental objectives. Journal of Applied Ecology, vol. 41, no. 6, p. 1021-1031.

HUGGETT, ASG. and WIDDAS, WF., 1951. The relationship between mammalian foetal weight and conception age. The Journal of Physiology, vol. 114, no. 3, p. 306-317.

KAREN, A., El AMIRI, B., BECKERS, JF., SULON, J., TAVERNE, MAM. and SZENCI, O., 2006. Comparison of accuracy of transabdominal ultrasonography, progesterone and pregnancy-associated glycoproteins tests for discrimination between single and multiple pregnancy in sheep. Theriogenology, vol. 66 , no. 2, p. 314-322.

KEYSER, PD., GUYNN Jr., DC., MATT KNOX, W., KAMMERMEYER, KE. and CRUM, JM., 2006. Response of adult sex ratios to simulated harvest strategies in white-tailed deer. Wildlife Society Bulletin, vol. 34, no. 5, p. 1273-1279.

LÓPEZ-BARBELLA, S., 1987. Consideraciones generales sobre la gestacion del chigüire (Hydrochoerus hydrochaeris). Acta Cientifica Venezolana, vol. 38, no. 2, p. 84-89.

MACDONALD, DW., 2006. The Encyclopedia of Mammals. 2 ed. Oxford: Oxford University. 930 p.

MILNER, JM., NILSEN, EB. and ANDREASSEN, HP., 2007. Demographic side effects of selective hunting in ungulates and carnivores. Conservation Biology, vol. 21, no. 1, p. 36-47.

MOREIRA, JR. and MACDONALD, DW., 1995. Simulação do efeito da seleção de sexo no abate de capivaras (Hydrochaeris hidrochaeris) na Ilha de Marajó - Pará. In BACELLOS, AO., MARIANTE, AS., ROCHA, CMC. and LEITE, GG. (Eds.). Anais da 32 a Reunião Anual da Sociedade Brasileira de Zootecnia. Brasília: Sociedade Brasileira de Zootecnia. p. 399-402.

MOREIRA, JR. and MACDONALD, DW., 1996. Capybara Use and Conservation in South America. In TAYLOR, VJ. and DUNSTONE, N. (Eds.). The Exploitation of Mammal Populations. London: Chapman \& Hall. p. 88-101.

MOREIRA, JR. and MACDONALD, DW., 1997. Técnicas de manejo de capivaras e outros grandes roedores na Amazônia. In VALLADARES-PÁDUA, C. and BODMER, RE. (Eds.). Manejo e Conservação de Vida Silvestre no Brasil. Brasília: Conselho Nacional de Desenvolvimento Científico e Tecnológico. Chap. 11, p. 186-213.

OJASTI, J., 1973. Estudio Biologico del Chigüire o Capibara. Caracas: FONAIAP. 271 p.

OLIVEIRA, JA. and BONVICINO, CR., 2006. Ordem Rodentia, 347-406. In REIS, NR., PERACCHI, AL., PEDRO, WA. and De LIMA, IP. (Eds.). Mamíferos do Brasil. Londrina: Editora da UEL. p. 347-406.

PRESS, WH., FLANNERY, BP., TEUKOLSKY, SA. and VETTERLING, WT., 1993. Numerical Recipes in C: the art of scientific computing. 2 ed. Cambridge: Cambridge University. $994 \mathrm{p}$.

TANG, S. and CHEN, L., 2002. Density-dependent birth rate, birth pulses and their population dynamic consequences. Journal of Mathematical Biology, vol. 44, no. 2, p. 185-199. 